\title{
Implementation of Curriculum in Multicultural Communities of BIPA Universitas Negeri Malang, Indonesia
}

\author{
Febby Aryani Asfianti Dewi \\ Department of Educational Management \\ Universitas Negeri Malang, Indonesia \\ febbyaryani.1901327@stundents.um.ac.id
}

\author{
Mustiningsih \\ Department of Educational Administration \\ Universitas Negeri Malang, Indonesia \\ mustiningsih.fip@um.ac.id
}

\author{
Lalu Habiburrahman \\ Department of Educational Management \\ Universitas Negeri Malang, Indonesia \\ laluhabiburrahman1901328@students.um.ac.id
}

\begin{abstract}
The application of the curriculum in the teaching and learning process is important in an education system. Therefore the curriculum is a tool to achieve the target of the education system, the curriculum is also used as a tool to achieve educational goals and can also be used as a guide in organizing educational activities also regarding all types and levels of education, the curriculum is also part of the learning process that allows participants students to find out the target to be obtained. The method used is descriptive qualitative and data collected from the results of focus group discussions and observations made by BIPA institutions.
\end{abstract}

Keywords: implementation curriculum, multicultural, ACTFL, BIPA

\section{INTRODUCTION}

Regarding the multicultural education curriculum (ethnicities, traditional religions, and groups that interact with each other in living together, even though they are very different certainly longing for peace, harmony, and social harmony. (Sutjipto, Wibowo, and Hastutiningsih 2017) Cultural diversity there are some notes. First, all countries in the world have educational curriculum policies that favor the principles of sustainability learning. Secondly, socio-cultural diversity in social ties that forms groups that have spread throughout civilizations in the world that support the same relationship with each other to be reflected in curriculum. Third, there are different groups of different races,

The multicultural education curriculum is also a place to increase individual and social capacity of each student in terms of social competencies in the form of the ability to socialize, adapt, interact in society, establish social relations, foster character, foster innovation and creativity, leadership and entrepreneurial spirit of students.

Maddux, et al. (2014) revealed that the psychological approach of individuals when in a multicultural environment, where they are involved with different cultures and determine the integrative complexity. The results of Maddux's research, et al. (2014) mean that professional workforce can be increased through education and influenced with the application of multicultural values. In a sense, through a multicultural education curriculum there is an effort to build national competitiveness and social harmony. Thus, students are more open in accepting all differences, have an attitude of tolerance to preach social life, and other roles that surround them, so that global competition and social cohesion in a plural society will be created.

The application or implementation of multicultural curriculum that is fiber with social experience and multicultural life situations along with the closeness to cultural modernization designed by the school community, is in the main position to determine the way of life of other groups, in terms of affiliation to religious and socio-cultural conditions.

BIPA is one of the institutions under the auspices of the State University of Malang (UM) and managed by the Faculty of Literature. An institution used as a forum for learning Indonesian for foreign communities. This unit routinely implements Indonesian language and culture learning programs for international students.

\section{METHOD}

This study seeks to collect data and information relating to the application of the curriculum at BIPA Malang State University by using a qualitative approach, the researcher focuses on actual problems through data collection. The source of this research data is one of the teachers who teaches at BIPA, as an informant, he has more or less already ordered the information needed in this study, he has become a senior teacher so that the data we need can be obtained easily. Before conducting research, the researchers found first made a research instrument that is the interview guide, and after the research instrument was completed then made observations with informants to conduct the interview stage. After obtaining the results of the interview then the data analysis is carried out according to the focus of the study.

\section{RESULTS AND DISCUSSION}

The root of the word multiculturalism is culture. Etymologically, multiculturalism is formed from the words multi (many), culture (culture), and ism (flow / understanding). Essentially, the word contains recognition of the dignity of the people who live in their communities with their unique cultures. Multiculturalism can be interpreted as diversity or difference between one culture and another culture (Lestari, 2016). So that multicultural societies can be interpreted as a group of people who live and live permanently in a place that has its own culture and characteristics that are able to distinguish between one society and another. 
The understanding of culture among experts must be at stake or contrasted between one concept that belongs to one expert and another expert's concept. Because multiculturalism is an ideology and a tool or vehicle to increase the degree of humanity and humanity, then the concept of culture must be seen in the perspective of its function for human life.

Curriculum Many people think that curriculum is related to teaching materials or textbooks that students must have, so that changes in curriculum are identical to changes in textbooks. Curriculum issues are not just textbook problems but many other issues includingproblems and educational goals. The subject matter matter, as well as other problems related to it. The term curculum was first used in the world of sports in ancient Greece which comes from the word curird and curere. At that time the curriculum was defined as the distance that a runner had to travel. People term it with a race or run from start to finish. Furthermore, the curriculum is used in the world of education. Educational experts have different interpretations of the curriculum. However, in different interpretations, there are also similarities. The similarity is, that the curriculum is closely related to efforts to develop students in accordance with the objectives to be achieved.

The ACTFL Proficiency Guidelines are an illustration of what a person can do with language for speaking, writing, listening and reading skills in real situations in context without preparation and spontaneity. For each skill, this guideline identifies three main levels of proficiency which are divided into High, Medium and Low sublevels. The levels in the ACTFL Guidelines describe the continuum of proficiency from the level of highly educated language users who are very fluent to a level of functional ability that has little or no ability at all.

This guide presents the level of proficiency as a stretch and a description of what someone does and can do with language at every level, regardless of where, when, or how the language was acquired. These levels together form a hierarchy that each level includes all levels below it. This guideline is not based on a particular theory, educational method, or educational curriculum. This guideline also does not describe how a person learns a language or formulates how a person should learn language, and this guideline should not be used for these purposes. This guideline is an instrument for evaluating functional language skills.

The ACTFL Proficiency Guidelines were first published in 1986 as an adaptation for the academic community for the Description of Interagency Language Roundtable (ILR) Skill Levels from the United States Government. This third edition of the ACTFL Proficiency Guidelines includes the first revision of the Listening and Writing Guidelines since their initial publication in 1986, and the second revision of the ACTFL for the Speaking and Writing Guidelines, which was revised to reflect the need for assessment in actual successive situations. The direct application of the ACTFL Proficiency Guidelines is as an evaluation of functional language skills.

The ACTFL Proficiency Guidelines underlie the development of ACTFL Performance Guidelines for learners with National Standards for Foreign Language Learning to illustrate how well learners meet content standards. Over the past 25 years, the ACTFL Guidelines have had an increasingly greater impact on language learning and teaching activities in the United States.

The results obtained after the study counted that there were a lot of programs run by BIPA in a one-year period, including the Critical Language Scholarship (CLS) program, the Indonesian Flagship Language Initiative (IFLI), the In-Country Program, Kasesat, Saga, Darma students, KNB and Private. The CLS and IFLI programs are special programs for the American Council that work together with BIPA UM in the form of a Memorandum of Understanding, and the people registered in this program must have a student status, while the CLS program applies to undergraduate, postgraduate and doctoral students while IFLI is only for, the difference is the CLS program is specifically for students who are related to foreign departments while the IFLI must be from the defense department.In the CLS and IFLI programs are not only taught in the Indonesian language but also given an introduction to cultures in Indonesia. students are carried out inside and outside the classroom Activities in the classroom include language classes and elective classes while activities outside the classroom include tutorial and excursion classes. The elective and excursion classes are classes that function to introduce tangible Indonesian culture (tangible culture).

The In-country Program is a university to university ( $\mathrm{u}$ to $\mathrm{u}$ ) program in cooperation between Malang State University (UM) and Walailak University Thailand. The program, which is attended by students majoring in ASEAN Studies, provides Indonesian language learning for six months. Unlike the other BIPA programs at UM, students who take the In-Country program also carry out KKN (Kuliah Kerja Nyata) like regular students. The Community Service Program which is held for 2-3 weeks in rural areas aims to make students not only understand the language used in the classroom, but also to know the variety of Indonesian used outside the classroom. In addition, they can also feel the real life in the countryside.

Kasesat program was adopted from the name of the university in Thailand, the University formed an MoU relationship or made agreements with several campuses in Indonesia and one of them was UM. So, it is certain that the kasesat program only contains students from Thailand. The students were sent to deepen and practice the Indonesian they had learned. Language classes were held intensively for 20 hours / week. Meanwhile, when the student culture class visited supporting places, such as Malang City, Batu City, Blitar City, and Mount Bromo. In addition, every day after language classes, they take gamelan classes. Another similar program is Saga, except that Saga is filled by students from Saga University in Japan.

Private program is a program that is made for anyone regardless of whether he is a student or not who wants to learn Indonedia with a specific goal or just deepen language understanding, for example people who want to learn Indonesian to facilitate interacting and communicating with the community because they will conduct research in error one or several people who will work in Indonesia so that they need good Indonesian 
language skills. Even in this program the material and vocabulary taught are tailored to the needs of students.

In the darma program students consist of foreigners from various countries both students or the general public who want and are interested in learning Indonesian and are funded by the Indonesian government, and of course not only learn languages but also learn Indonesian culture. The condition is that a country must have bilateral relations with Indonesia so that the Indonesian Embassy will be built in that country. So foreign students who want to study can register at the Indonesian Embassy and after being accepted they will be sent to Indonesia at several campuses that have the BIPA program. The foreign student will learn Indonesian for 1 (one) year, the administration of which is fully borne by Indonesia, which is managed through the International Relations office. Not much different from the student darma program, the KNB program is also a scholarship program whose costs are borne by the Indonesian government, and only applies to graduate students who wish to continue their studies at UM. learning activities are divided into two, language classes and culture classes. Usually, the cultural class that is held is the gamelan class. However, it should be noted that the implementation of the Darmasiswa program at each university is different.

In accordance with the data we found in the field that UM UMA does not use the national curriculum as used in schools, but instead adopts a curriculum or assessment system from America, namely ACTFL. This assessment system is used since the formation of the IBIP until now, and has never been made changes or ratification of these assessment points, because according to the interviewees the curriculum is very fitting to be applied in BIPA. ACTVL is recommended by the Americans, a curriculum that was specifically formed for language learning. This curriculum divides the class into three levels namely low, mediate and intermediate, then each level is also divided into three. Just like learning in general, each level has a learning goal or goal that must be achieved. Students will be known to reach the goal after an evaluation. To support the learning process, every student who studies at BIPA is provided with 2 (two) mentoring tutors, this tutor will provide real practice from the learning that the teacher provides. The most frequently encountered problem is the diversity of students' level of knowledge of Indonesian, which is done by the teacher in dealing with this is by giving some special treatment about the lack of the ability of the students.

\section{CONCLUSION}

The curriculum is used as a guide in conducting the teaching and learning process, for language learning in BIPA, applying a different curriculum that is different from the national standards in Indonesia. According to him ACTFL which is a curriculum used in BIPA institutions, was made specifically for foreign language learning, so this curriculum is used from the beginning until now and has not gone through the stages of change. In carrying out its programs, BIPA not only teaches Indonesian but also provides an introduction and learning about various cultures that exist in Indonesia. Some things become obstacles in the implementation of this curriculum, but solutions can be found without making changes to the curriculum components. But that does not mean that changes will not occur in the future, it's just that for now the components and inducators that are in ACTFL are the most suitable to be applied in BIPA.

\section{REFERENCES}

[1] Arumdyahsari, S. 2016. Pengembangan Bahan Ajar Bahasa Indonesia bagi Penutur Asing (BIPA) Tingkat Madya. Malang: BIPA UM.

[2] Azis, R. 2004. Implementasi Pengembangan Kurikulum. Malang: Elang.

[3] Multikulturalisme, A. P. 2006. Pendidikan Multikultural. Yogyakarta: Pustaka Pelajar.

[4] Rahmat, H. 2011. Pengantar Sosiologi Kurikulum. Jakarta: PT Rajagrafindo Persada.

[5] Sukiman. 2015. Pengembangan Kurikulum Perguruan Tinggi. Bandung: PT Reamaja Rodakarya.

[6] Sutjipto, S., Wibowo, U. B., and Hastutiningsih, A. D. 2017. Implementasi Kurikulum Multikultural di Sekolah Dasar. Jurnal Pendidikan dan Kebudayaan, 2(1), 1.

[7] Sutjipto, S., Wibowo, U. B., and Hastutiningsih, A. D. 2017. Implementasi Kurikulum Multikultural di Sekolah Dasar. Jurnal Pendidikan dan Kebudayaan, 12, 1-8.

[8] Tias, R. F. 2019. Aplikasi Indonesia Satu: Digitasi Multikultural Indonesia, Jurnal Pendidikan dan Kebudayaan, 12, 9-18.

[9] Wina, S. 2008. Kuriulum dan Pembelajaran. Jakarta: Kencana Media Prenada Group.

[10] Zamahsari, G. K., and Roffi'uddin, A. H. 2019. Implementasi Scaffolding dalam Pembelajaran BIPA di Kelas Pemula. Jurnal Pendidikan, 4(1), 68-78. 